\title{
Escravos bem falantes e nacionalização linguística no Brasil - uma perspectiva histórica
}

\section{Well spoken slaves and linguistic nationalization in Brazil - a historical approach}

Ivana Stolze Lima

O objetivo deste texto é discutir alguns aspectos da história da nacionalização linguística do Brasil e especialmente sua articulação com a escravidão de africanos e descendentes. Pretende-se assim contribuir para uma visão crítica sobre a relação entre língua e história social.

A expressão "países de língua portuguesa" parece sugerir, ao ouvido pouco atento, ideias de unidade que existiriam tanto entre os diferentes países como internamente em cada um deles. No entanto, o exame atento mostra como as diferenças e tensões afloram a todo momento e o quanto essa unidade é mais projetada do que efetiva. Na maioria dos chamados países de língua portuguesa,

Ivana Stolze Lima é pesquisadora do Setor de História da Fundação Casa de Rui Barbosa e professora de História do Brasil na PUC-Rio (ivanastolze@gmail.com).

Esta pesquisa recebeu financiamentos do CNPq e da Faperj.

Artigo recebido em 30 de junho e aprovado para publicação em 14 de agosto de 2012. 
essa língua não é a língua materna predominante e nem é falada pela maioria da população, e tensões que podem surgir dos diferentes status das línguas atravessam o cotidiano e tornam visíveis desigualdades sociais e políticas. ${ }^{1}$ Além da dimensão simbólica que a suposta ideia de unidade carregaria, retirando a ênfase das ações políticas e dos dramas envolvidos na coexistência das línguas oficiais e das práticas linguísticas dos diferentes grupos, deve-se considerar criticamente os interesses da indústria e toda a movimentação da economia relacionada à promoção dessa unificação.

Também no Brasil, onde o português é a língua materna da maioria da população, não deixa de ser importante observar as cisões internas que atravessam uma aparente unidade linguística. A hierarquização e a exclusão feitas a partir do uso da língua escrita "correta" é hoje, provavelmente, um dos problemas mais cotidianos do acesso a determinados circuitos sociais e intelectuais, e o preconceito linguístico é extremamente naturalizado. Em outras palavras, as divisões que a língua reitera na sociedade estão fora do debate público. Em perspectiva histórica, tanto o processo social que constrói uma unificação linguística, sempre inacabada, como os sentimentos e representações em torno da "nossa língua" e das "outras línguas" são aspectos que enriquecem esse questionamento e levam a uma desnaturalização da ideia de que um país tem sempre uma língua.

Mesmo que "língua portuguesa" seja a forma tanto oficial como corrente de nomear a língua dominante no Brasil, é válido recuperar uma trajetória de idas e vindas. Assim, em diferentes momentos do século XIX, desde a independência, buscaram-se alternativas em expressões mais fortes, como "língua brasileira", ou mais atenuadas, como "língua nacional" ou "dialeto brasileiro". A Constituição de 1824 não fez referência ao tema, mas em diferentes campos discursivos, como a literatura, relatórios oficiais, títulos de obras, legislação, essa variação na denominação esteve presente. Mais do que a relação com Portugal, a motivação para tais denominações nacionalistas assentava-se em uma preocupação com a coesão interna (Lima, 2007 e 2008). As primeiras leis de instrução pública definiam como um dos objetivos ensinar a "língua nacional" aos futuros cidadãos da pátria, sendo este um dos caminhos para se chegar a um "modo geral de sentir" (Mattos, 1990: 251), indispensável para o projeto político saquarema: um Estado centralizado, sob a direção da classe de proprietários de terras e de escravos, em um regime de monarquia constitucional. Era consenso que Portugal havia posto o Brasil no caminho da civilização, e o atributo de uma língua civilizada deveria assim ser preservado.

A produção intelectual acerca da nacionalidade da língua foi muito fecunda nas últimas décadas do século XIX e início do século XX, com diferentes pesquisas sobre brasileirismos, tupinismos, africanismos, bem como acalo- 
rados debates sobre os rumos diferenciados da língua na América e em Portugal, sobre os princípios que regeriam a ortografia, sobre a distância entre a língua falada e a língua literária. Trata-se de uma produção muito vasta, que não caberia sintetizar neste artigo. Cabe contudo apontar o quanto essa mobilização foi a base para que a Carta de 1934 recorresse ao eufêmico "idioma pátrio" ao legislar sobre o ensino. Outros exemplos foram a tentativa de firmar, através da lei, a expressão "língua brasileira", que se deu em 1935 no Distrito Federal, e um debate parlamentar nos anos de 1930 e 1940 sobre qual seria a expressão mais apropriada: língua brasileira ou língua portuguesa (Sanches, 1940). A polêmica se manteve na Constituição de 1946, que estipulou que não poderiam ser eleitores tanto os analfabetos quanto os "que não saibam exprimir-se em língua nacional”. Permanecia em aberto a denominação da língua: nas Disposições Transitórias dessa Constituição, estabeleceu-se que o governo nomearia uma comissão para opinar sobre a "denominação do idioma nacional". Em 1967, a Constituição outorgada pelo regime civil-militar manteve o "idioma nacional" como parâmetro para o ensino e para que um cidadão pudesse ser eleitor. Na Constituição de 1988, pela primeira vez, definiu-se a "língua portuguesa" como o idioma oficial da República. O reconhecimento do Brasil como país multilíngue foi formalizado pela inclusão, na questão das comunidades indígenas, do direito ao uso das suas línguas maternas.

Vale a pena nos debruçarmos sobre o conceito de língua e seu uso como fator de identidade e de uma suposta coesão interna de Estados nacionais. Historicamente, longe de ter sido um processo espontâneo ou natural às formações sociais, as línguas nacionais do mundo moderno europeu formaram-se a partir de projetos específicos de estabelecimento de normas ligados à expansão da cultura escrita. Segundo Pierre Guisan (2009: 22), uma koiné escrita, articulada pelo movimento intelectual e editorial no início da era moderna, surgiu antes de uma língua falada em comum. Em cada um dos países como Espanha, Itália, França, Alemanha e Inglaterra, a despeito de variações e particularidades, esse processo foi semelhante. As elites cultas desses países teriam começado a falar essa língua escrita que, mais tarde, tornou-se a língua das escolas e enfim padronizou-se em uma língua standard. Como sintetiza esse autor:

A invenção da imprensa, do caracter móvel, a criação de um mercado capitalista para um novo bem comercial, o livro, destinado a ser adquirido por indivíduos, com uma rede de escritores, de editores, de impressores e de livreiros, vão dar um forte impulso para a realização efetiva desse projeto de criação de uma norma, indispensável para assegurar o sucesso deste empreendimento capitalista, que dará a forma a 
outro projeto mais ambicioso ainda: o da formação dos Estados nacionais e da definiçãa dos seus limites territoriais (Guisan, 2009: 19).

Na medida em que as línguas constituem sistemas dinâmicos, em constante variação, o questionamento das fronteiras linguísticas se impõe. $O$ nome atribuído a uma língua revela escolhas políticas e apreende o contínuo variável das línguas maternas, com todo seu espectro de regionalismos e transformações contínuas dentro de certas molduras através das quais são reiteradas as representações identitárias de determinada sociedade em um suposto quadro de estabilidade e coerência (Guisan, 2009: 24). A fronteira do Estado nacional não se confunde com a fronteira linguística, senão à custa de ações específicas e constantemente repetidas para que tal uniformização se atualize. As fronteiras se esmaecem também quando se considera as inúmeras formas de trânsito linguístico, provocadas por migrações, comércio, artes. As experiências de multilinguismo e contato marcam a história de diferentes povos e épocas. O problema ocorre quando determinadas línguas assumem determinados status (Calvet, 2007: 58) por exemplo, de língua oficial, de língua do sistema de justiça e administrativo, de língua de ensino, de língua escrita, em detrimento de línguas que compõem formas de comunidade e tradição distintas.

Michel de Certeau analisou o processo de expansão do francês na Revolução Francesa e traça uma periodização que permite pensar uma mudança importante entre o mundo moderno e o mundo contemporâneo, marcado pela formação dos Estados nacionais. No Antigo Regime, quando impunha a língua francesa escrita nos atos públicos, a monarquia tinha em vista as elites e procurava agir contra os particularismos que dificultariam a administração. A nova ordem política instaurada pela Revolução, em uma mudança significativa, passou a visar uma adesão popular à uniformidade linguística falada e escrita, em um processo que buscava claramente anular as culturas periféricas. Assim, de uma língua regional, de domínio privado ou de cunho administrativo, o francês passou a ocupar o lugar de uma língua pública e nacional (Certeau et alii, 1975).

As discussões sobre a história linguística do Brasil têm gerado uma vasta bibliografia dedicada ao tema (por exemplo: Alkmim, 2002; Silva, 2001; Mello, 1996; Rodrigues, 1983). A implantação do português não constituiu um processo linear ou contínuo. Um aspecto significativo da colonização da América portuguesa foi o uso de línguas francas baseadas nas línguas tupi-guarani, adotado por diferentes grupos, incluindo índios falantes de outras línguas, europeus e africanos (Freire, 2004; Lee, 2005). Apenas no século XVIII, no contexto de expansão da colonização e estreitamento dos vínculos mercantilistas, é que uma política linguística para impor o português e proibir a língua geral nos aldeamentos indígenas seria minimamente exequível (Mariani, 2004). No mesmo pe- 
ríodo há um movimento intelectual de valorização da língua portuguesa em detrimento do latim que se manifesta na literatura e nas reformas educacionais. Do ponto de vista da história social, a interiorização da colonização, as trocas econômicas que articulavam não só a colônia à metrópole, mas as regiões coloniais entre si (Fragoso e Florentino, 2002; Villalta, 1997), a expansão das áreas urbanas, certo incremento administrativo, a contínua presença da Igreja católica devem ser igualmente levados em consideração para avaliar a expansão da língua portuguesa. Tal língua, no entanto, já vinha adquirindo cores locais, com novo vocabulário, novas pronúncias, novas sintaxes.

Pode-se considerar o quanto a escravidão de africanos e descendentes atuou na difusão do português. Uma das razões é que a escravidão foi um dos elementos básicos da economia colonial, fortalecendo consequentemente a presença metropolitana. Outra razão é que o português foi também usado como língua veicular por falantes de outras línguas, principalmente nas áreas urbanas e nas regiões em que essa língua era corrente - embora esse uso não deva esmaecer a consideração das formas de manutenção das línguas africanas no território (Petter, 2008; Galves, 2009; Lucchesi, 2008; Castro, 2002).

Aliás, um ponto essencial do questionamento de que um povo ou grupo étnico teria uma única língua é justamente considerar as diversas formas de trânsito linguístico e de alternância entre códigos. Assim como podemos imaginar como, ainda no século XVIII, os chefes de famílias paulistas falavam a língua geral tupi no domínio privado, e o português nas câmaras municipais, como Sérgio Buarque de Holanda comentou no clássico Raízes do Brasil (Holanda, [1936] 1971), a alternância de códigos ocorria a todo momento nos sertões, vilas e cidades, de acordo com a situação. Na região amazônica, por exemplo, Flavio dos Santos Gomes (2005: 87, 90 e 102) indica várias situações em que se percebe como os habitantes dos quilombos transitavam por diferentes línguas. Que língua usar dependeria assim de escolhas e dos interlocutores em questão. Outros condicionantes da situação linguística dos africanos e descendentes no Brasil seriam o ambiente urbano ou rural, o tamanho da propriedade escrava, o ofício, as formas de vínculo comunitário, assim como os condicionantes ligados ao tráfico. Um exemplo importante que sintetiza essas variáveis foi o uso da língua geral de mina documentado em Ouro Preto nas primeiras décadas do século XVIII. Uma determinada situação do tráfico atlântico e a demanda nas áreas mineradoras gerou uma grande concentração de falantes de línguas do grupo gbe, da região genericamente conhecida como Costa da Mina (Peixoto, 1945; Castro, 2002; Lara, 2002). Investigações sobre a língua geral de mina no Brasil constituem um campo ainda em aberto, sendo necessário reunir registros dispersos que talvez levem a um redimensionamento dessa presença. Situações semelhantes ocorreram na região cafeeira, no Vale do Paraíba, no século XIX, quando africanos falantes de 
línguas próximas, pertencentes ao tronco banto, puderam construir suas comunidades de palavra (Slenes, 1992; Abreu, 2012). O repertório linguístico que os africanos desembarcados encontrariam e que orientaria as suas práticas de comunicação dependeria portanto de condições variáveis. No caso da cidade do Rio de Janeiro, no período focalizado, duas balizas podem ser indicadas. Por um lado, trata-se de uma cidade que recebeu distintos grupos étnicos e linguísticos, e que foi marcada por grande concentração populacional escrava, o que tornou possível que africanos falantes da mesma língua se encontrassem ou usassem línguas gerais ou veiculares para se comunicar. A outra baliza marcante na experiência de comunicação da cidade foi a presença da língua portuguesa, com a qual os escravos que trabalhavam no ambiente urbano, exercendo determinados ofícios, teriam muito mais contato do que, por exemplo, em áreas de grandes plantations, em que as línguas africanas poderiam ter mais trânsito.

No momento em que o Brasil se tornou independente, constata-se uma situação bastante complexa. De um lado, se se considera a experiência linguística dos diferentes povos circunscritos ao território, constata-se um plurilinguismo formado por línguas indígenas, línguas africanas e outras línguas europeias e também pelas variedades do português em função dos regionalismos, do acesso diferenciado aos padrões cultos, bem como da condição de aquisição do português como segunda língua, válida para grande parte desses povos, notadamente para os africanos traficados para o Brasil. Nunca é demais lembrar que se estima que quase 2 milhões de africanos desembarcaram no país na primeira metade do século XIX. De outro lado, como comentado de forma breve no início do artigo, esse foi um momento de elaboração simbólica acerca da nacionalidade linguística do país. Isso ocorreu não só no campo da literatura romântica (Süssekind, 1994), mas mesmo antes, em diferentes campos discursivos ligados à história da imprensa e à política, como mostram alguns exemplos, entre eles a produção do Visconde da Pedra Branca sobre a diferenciação entre a "língua portuguesa" e o “idioma brasileiro" (Alkmim, 2012), e o Dicionário da língua brasileira, publicado em Ouro Preto em 1832. Além das representações em torno de uma autonomia no plano da língua nacional, as primeiras décadas do século XIX foram também um momento de expansão da cultura escrita, a partir das rápidas mudanças desencadeadas pela circulação da palavra impressa e das medidas para promover a instrução das primeiras letras (Lima, 2008). Também é interessante considerar a demanda que os grupos socialmente iletrados fizeram, de acesso à cultura escrita. A busca da leitura e da escrita por livres pobres, africanos e crioulos, escravos e libertos, é algo cada vez melhor conhecido (Wissenbach, 2002; Silva, 2000; Oliveira e Lobo, 2007). Em síntese, plurilinguismo e um processo de nacionalização marcam esse momento. 
A forma como a literatura e dirigentes imperiais representaram a relação entre africanos e língua nacional contrasta com a dimensão das interações sociais no cotidiano no mundo escravista. Apesar de algumas iniciativas bem pontuais que observavam a influência de africanos no léxico da língua portuguesa, como as do já citado Visconde da Pedra Branca e Brás da Costa Rubim (1853), de uma forma geral escritores e representantes políticos deram mostras de um sentimento generalizado que associava os africanos a uma corrupção da língua. Varnhagen é um exemplo rico dessa ambiguidade, pois se de um lado ele registra um léxico africano presente no Brasil, de outro vocifera contra a corrupção da "mocidade", dos costumes e da língua causada pelos africanos.

São também da África as palavras quitanda, quenga, senzala, calundum, caçula, bunda, mocotó, tamina, moxinga, mocambo, quilombo, matombo, mazombo, marimbondo, quinguangu, curingu, cabungo e outras muitas, incluindo várias que passaram à Europa, tais como: coco, papagaio, macaco, muringue, cacimba, tanga, quindins, jerebita, moleque e outras (Varnhagen, 1975: 225).

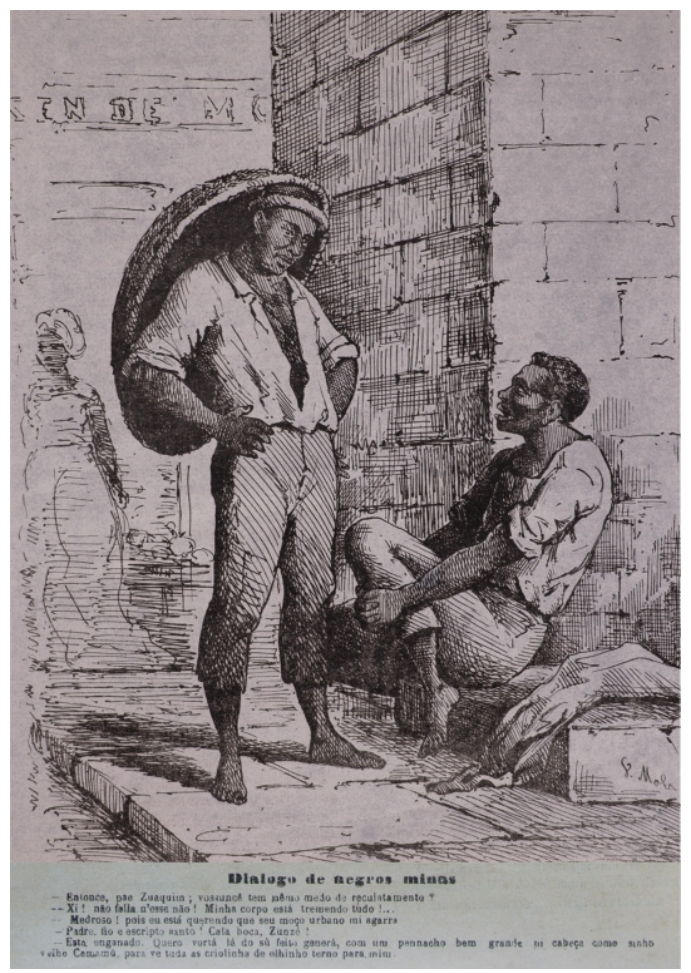


Mas ele logo se apressa em acrescentar que os colonos africanos "pervertiam os costumes, por seu hábitos menos decorosos, seu pouco pudor e sua tenaz audácia” (Varnhagen, 1975: 225).

Expressões pejorativas como "geringonça luso-africana", "português caçanje", "português nagô", ou "português bunda" são exemplos dessa associação entre os africanos e o que se via como um uso incorreto e "estropiado" da língua. A literatura oitocentista deu continuidade ao estereótipo da fala escrava com personagens que se expressavam com marcas fonéticas e gramaticais características (Alkmim, 2008), como na charge publicada em 1868 que acompanha este artigo: reculatamento?
-Entonce, pae Zuaquim; vossuncê tem mêmo medo de tudo!...

- Xi! Não falla n'esse não! Minha corpo está tremendo mi agarra

- Medroso! pois eu está querendo que seu moço urbano

- Padre, fio e escripto santo! Cala boca, Zunzé!

- Esta enganado. Quero vortá lá do sù feito generá, com um pennacho bem grande ni cabeça como sinho velho Camamú, para ve tudo as criolinha de olhingho terno para mim. (Vida Fluminense, $11 / 1 / 1868)$

O contraponto entre o papel literário atribuído à língua tupi e certa denegação da influência das línguas africanas é interessante. Abrindo as páginas da produção literária oitocentista, que prezou o vínculo com a oralidade (Süssekind, 1994), nos deparamos com um vocabulário que seria mais tarde identificado como de procedência africana, e que já estava automatizado como língua corrente, ainda que não houvesse a pompa e circunstância, e mesmo certo artificialismo, que cercava o uso das palavras tupi no texto literário. A título de exemplo, podemos consultar a obra ficcional do período, em que nos deparamos tanto com palavras originadas nas línguas africanas como com usos próprios dos falares dos escravos.

Entretanto, uma investigação seriada utilizando anúncios de jornais relativos a escravos mostrou facetas novas dessa relação. A análise dos anúncios evidenciou outra perspectiva, em que a desenvoltura e a apropriação da língua corrente pelos escravos predominam sobre os problemas e dificuldades. Partindo de dois jornais de publicação diária no Rio de Janeiro, Diário do Rio de Faneiro (DRJ), a partir de 1821, e Fornal do Comércio (JC), a partir de 1827, tendo como marco final o ano de 1870, a pesquisa acumulou informações sobre $602^{2}$ escravos 
que fugiram, dos quais 360 africanos de diferentes nações, 188 crioulos de várias partes do país, e 48 cuja origem não foi determinada, além de 2 escravos de Montevidéu e 1 da Martinica. São homens e mulheres, de todas as faixas etárias, muitos com ofícios ou habilidades mencionadas, além de características físicas e psicológicas através das quais o proprietário daria pistas para que o seu escravo fosse identificado.

Essa documentação apresenta uma forma de discurso relativamente espontânea, próxima da oralidade, ainda que mesclada a fórmulas e padrões correntes. Além disso, representa grupos variados, uma vez que a propriedade escrava era pulverizada em distintos níveis sociais, abrangendo tanto grandes como pequenos proprietários. Em comparação com os anúncios de venda ou aluguel de escravos, que visavam caracterizá-los tendo em vista uma defesa de suas qualidades e aptidões, nos anúncios de fuga a descrição dada pelos proprietários buscava antes uma identificação dos fujões. $\mathrm{O}$ ato de descrever traduz um olhar bastante fino e perspicaz, que tanto expõe a situação de força do proprietário, seus valores, sentimentos e expectativas, como também, de certa forma, revela muito da relação mantida com o escravo. ${ }^{3}$ Apostamos assim que, a partir do registro do proprietário, a descrição acaba por trazer indícios sobre as próprias práticas dos escravos. Marcelino era um pardo que pertencia a Zeferino José Pinto de Magalhães. Fugiu nos primeiros dias de 1823. Era "bastante feio e carrancudo", e levou roupas muito sujas. Mesmo assim, o proprietário acrescentou algo que o distinguia: "seu modo de falar é muito persuasivo e claro" e "diz a todos que é escravo do excelentíssimo ministro de Estado Sr. José Bonifácio de Andrada" (DRJ, 8/1/1823). Magalhães, ou outro que tenha feito a descrição, demonstra uma ambigüidade, pois se Marcelino mentia, dizendo pertencer ao ministro, por outro lado se advertia que ele poderia persuadir seus ouvintes.

As descrições nos levam a imaginar a íntima e tensa relação que senhores e escravos travavam na interação do dia a dia, no rosto e na expressão, na boca, no ouvido e no olhar. Ainda que se constituindo de uma fala senhorial, impressiona o grau de intimidade ali testemunhado. Afinal, intimidade e domínio senhorial eram intrínsecos em algumas situações da escravidão (Chalhoub, 1990). As posturas e comportamentos dos escravos aparecem em gestos e modos: "olha para baixo quando fala", "fala macia", "pernóstico", "humilde no falar", "fala corretamente". A descrição que um senhor faz de seu escravo torna-se, portanto, uma fonte rica de observação das performances e práticas dos escravos. Se por um lado atualizam as fronteiras e as formas de classificação e hierarquização da lógica senhorial, por outro evidenciam a perspectiva dos escravos na sua experiência cotidiana.

O interessante é que apontar tais gestos e modos poderia ser realmente muito eficaz na identificação, uma vez que se trataria de algo corriqueiro, automático, que apontava idiossincrasias de alguns escravos. Feliciano, de Nação Moçam- 
bique, fugiu em 1838 junto com Maria, de nação Benguela, ambos com cerca de 30 anos. Eram propriedade de Domingos Gonçalves Valle, de São João Marcos do Príncipe, área importante de produção cafeeira no Vale do Paraíba. Sobre Feliciano, se disse que "fala bem a língua portuguesa, mas tem a fala grossa e vagarosa". Já Maria "não pronuncia bem o português, quando está assustada gagueja no falar" (JC, 14/2/1838). Vemos habilidades distintas na língua senhorial, e ao lado da observação dessa habilidade - importante sinal quando se tratava de africanos - vinham notas sobre a fonação, como a voz grossa e vagarosa e mesmo sobre a dificuldade de gaguejar no caso do susto. Nesse caso, Maria se trairia. Interessante imaginar ainda em que língua o casal se comunicaria, se no português fluente de um, se na pronúncia falha da outra, ou se em uma língua africana.

Outras descrições mostram também o quanto o senhor não procurava descrever o escravo senão numa relação onde se espera submissão. Agostinho, crioulo, com a profissão de carpinteiro, aparece como "mal encarado e quando fala não encara" (DRJ 2/6/1848). Já Luiz, de nação Angola, fingindo-se forro, parecia mais desafiador: foi descrito como "mal encarado quando fala" (JC, 16/4/1863). Francisco, crioulo de Minas, fugiu da Tijuca. Era ferrador, tinha mais de 40 anos, era "reforçado de corpo", tinha cabelos já brancos e era "muito humilde no falar" (JC, 12/2/1840). Manoel, um rapaz mais jovem, que sabia ler e escrever um pouco, fugiu da fábrica de chapéus de José Wamovy: "quando se fala com ele mostra-se meio assustado" (DRJ, 16/3/1837). Raimundo Cabra fugiu em Vassouras, tendo sido visto com um outro escravo em viagem para a Corte, e tinha a "fala acanhada" (JC, 10/1/1861). Afinal, os senhores estavam descrevendo os seus escravos para outros senhores. A expressão "fala atrapalhada", mais corrente para africanos, é um outro bom exemplo da perspectiva do ouvido senhorial. De alguém que não entendiam, diziam ter uma fala atrapalhada, embaraçada. Esses exemplos apontam como o peso da escravidão influía na própria forma de comunicação entre os que a sofriam. Provável consequência desse peso, há cerca de $5 \%$ de problemas de gagueira referidos nos anúncios.

No entanto, essa relação de dominação que se atualizaria constantemente na humildade, no acanhamento, no susto e sufoco ao falar com os senhores, não foi a única forma de relação que os anúncios registraram. Na verdade, como será demonstrado nas tabelas 1 e 2 , esses constituem a menor parte dos casos. A análise de conjunto mostra antes um intenso trânsito linguístico entre senhores e escravos, independentemente do fato de que as formas de comunicação assinalavam lugares sociais definidos. José era um pardo de 10 anos, "meio claro, de bonita figura, muito ativo na pronúncia" (JC, 21/9/1836). A questão da beleza do negro percebida pelos senhores é um campo que tem muito ainda a ser explorado. O interesse pelas representações imagéticas dos diferentes africanos, os tipos, as etnias, as roupas, cabelos, gestual não foi concretizado apenas nas gravuras, 
desenhos e fotografias oitocentistas. Nos anúncios registra-se também o interesse e certa atração pelo escravo em descrições que incidem sobre a visualidade e a exteriorização dos códigos sociais. A caracterização do escravo "bem parecido", "bonito de cara", "bonito e bem feito", "bonito e bem falante", "de bonita figura" foi comum. Ainda que não caiba neste texto a análise cuidadosa desse aspecto, essa observação é importante para complementar os dados sobre as descrições positivas de como os escravos crioulos e africanos se comunicavam. Como não imaginar uma das fotografias das mulheres minas de Augusto Stahl, feitas na década de 1860 (Souza, 2011), ao vermos a descrição de Genoveva, nação Mina Nagô - "bonita de cara, fala muito bem, tem uma cor mui preta, os sinais de nação quase não aparecem, alta, magra, bem feita do corpo, levou toda a sua roupa"? (DRJ, 1/4/1842).

Dos 188 escravos crioulos, classificamos 97 (ou 51,5\%) como tendo uma boa habilidade linguística, ${ }^{4}$ destacando as seguintes expressões: "fala bem" (15), "bem falante" (18), "fala desembaraçada" (10), entre outras menos numerosas

Tabela 1. Descrições dos escravos crioulos ${ }^{5}$

\begin{tabular}{|c|c|c|c|}
\hline $\begin{array}{l}\text { Classificação das } \\
\text { descrições }\end{array}$ & $\begin{array}{l}\text { Número de } \\
\text { crioulos }\end{array}$ & $\%$ & Exemplos \\
\hline Boa habilidade & 97 & 51,5 & $\begin{array}{l}\text { fala bem (15), bem falante (18), sabe ler e } \\
\text { escrever (24), muito falador/faladeira (7), fala } \\
\text { desembaraçada (10), fala explicada/ } \\
\text { inteligível/explica-se bem/fala bem expressado } \\
\text { (7), ladino (3) e outras }\end{array}$ \\
\hline $\begin{array}{l}\text { Características } \\
\text { psicológicas }\end{array}$ & 27 & 14,3 & $\begin{array}{l}\text { manso no falar, fala descansada, agradável no } \\
\text { falar, fala baixo e macio, fala vagarosa, quando } \\
\text { fala, é sempre com ar de riso, fala mansa, fala } \\
\text { descansada, cabeça sempre baixa quando fala, } \\
\text { meio apatetado quando fala }\end{array}$ \\
\hline $\begin{array}{l}\text { Fala atrapalhado/fala } \\
\text { embaraçado }\end{array}$ & 3 & 1,5 & $\begin{array}{l}\text { fala um tanto atrapalhado, fala muito } \\
\text { embaraçado }\end{array}$ \\
\hline $\begin{array}{l}\text { Falantes de um outro } \\
\text { idioma }\end{array}$ & 13 & 6,9 & $\begin{array}{l}\text { fala inglês, fala um pouco de espanhol, fala } \\
\text { francês }\end{array}$ \\
\hline Fanhoso & 2 & 1 & fala fanhosa \\
\hline Gago & 16 & 8,5 & bastante gago, gagueja quando fala \\
\hline Fonação/articulação & 5 & 2,6 & $\begin{array}{l}\text { quando fala, pega-lhe a língua, quando fala é } \\
\text { com muita pausa, fala muito grosso, fala fina }\end{array}$ \\
\hline $\begin{array}{l}\text { Sem informações sobre a } \\
\text { fala }\end{array}$ & 20 & 10,6 & \\
\hline Total & 188 & 100 & \\
\hline
\end{tabular}

Fontes: Diário do Rio de faneiro (1821-1870) e fornal do Comércio (1827-1870) 
como "falador", "faladeira", “fala explicada", "fala inteligível”, "fala de modo persuasivo e claro". Também classificamos assim os casos de alfabetização: "sabe ler e escrever" (24). No grupo dos africanos, a partir de expressões como "ladino", "fala bem a língua portuguesa", "fala perfeitamente", "fala como um crioulo", "fala desembaraçada", "bem falante", que indicam mais especificamente o grau de aquisição da língua portuguesa, a proporção é de $40 \%$, como pode ser visto nas tabelas. Os outros $60 \%$ de africanos foram descritos com aspectos variados, e apenas $17 \%$ foram classificados explicitamente como tendo um "mau" desempenho na língua senhorial. No caso dos crioulos, o grupo que claramente teria dificuldades em se comunicar, na perspectiva senhorial, seria também pequeno.

Tabela 2. Descrição de escravos africanos ${ }^{6}$

\begin{tabular}{lccl}
\hline $\begin{array}{l}\text { Classificação das } \\
\text { descrições }\end{array}$ & $\begin{array}{l}\text { Número de } \\
\text { crioulos }\end{array}$ & $\%$ & Exemplos \\
\hline $\begin{array}{l}\text { Boa habilidade na } \\
\text { língua portuguesa }\end{array}$ & 147 & 40,7 & $\begin{array}{l}\text { Ladino, fala bem a língua portuguesa, fala } \\
\text { perfeitamente, fala como um crioulo, fala } \\
\text { desembaraçada, bem falante etc. }\end{array}$ \\
\hline $\begin{array}{l}\text { Fraca } \\
\text { habilidade na língua } \\
\text { portuguesa }\end{array}$ & 64 & 17,7 & $\begin{array}{l}\text { Fala atrapalhada, fala embaraçado, boçal, não } \\
\text { fala bem o português, fala pouco o português, } \\
\text { fala o português muito mal }\end{array}$ \\
\hline $\begin{array}{l}\text { Média habilidade na } \\
\text { língua portuguesa }\end{array}$ & 23 & 6,3 & $\begin{array}{l}\text { Fala meio embaraçado, ladino e não fala bem } \\
\text { claro, fala pouco desembaraçada, não fala bem } \\
\text { explicado }\end{array}$ \\
\hline $\begin{array}{l}\text { Em processo de } \\
\text { pprendizagem }\end{array}$ & 22 & 6,0 & $\begin{array}{l}\text { Ainda boçal, ainda fala pouco o português, já } \\
\text { meio ladino, fala ainda meio atrapalhado }\end{array}$ \\
\hline $\begin{array}{l}\text { Características de } \\
\text { fonação/articulação }\end{array}$ & 41 & 11,3 & $\begin{array}{l}\text { Fala grosso, gagueja, fala fanhosa, fala rápido, } \\
\text { fala fina }\end{array}$ \\
\hline $\begin{array}{l}\text { Características de cunho } \\
\text { psicológico ou de gestual }\end{array}$ & 33 & 9,1 & Fala mansa, fala pouco, fala muito brando \\
\hline $\begin{array}{l}\text { Só com indicações de falar } \\
\text { um outro idioma }\end{array}$ & 4 & 1,1 & Fala francês, fala espanhol, fala inglês \\
\hline Inclassificáveis & 4 & 1,1 & muito falador e mal \\
\hline $\begin{array}{l}\text { Sem informações sobre a } \\
\text { fala }\end{array}$ & 22 & 6,0 & \\
\hline \begin{tabular}{l} 
Total \\
\hline
\end{tabular} & 361 & 100 & \\
\hline
\end{tabular}

Fontes: Diário do Rio de Faneiro (1821-1870) e fornal do Comércio (1827-1870)

Formamos outro grupo de descrições a partir de categorias psicológicas associadas à fala ("fala manso", "fala descansada", "fala muito brando", "fala 
macia") que na maior parte podem ser entendidas também como uma certa facilidade de comunicação. Outra categoria diz respeito a características de fonação/articulação como "fala devagar", "fala fina", "voz grossa", "fala apressada", que também não remetem a dificuldades explícitas, apenas a certas marcas. Separamos a categoria dos "gagos" desta última, na medida em que nesse caso explicitam-se sim problemas na comunicação. Para além das proporções aqui apontadas, julgo notável o grau de sensibilidade para essas diferenças, a acuidade de quem ouvia os escravos e criava a partir da audição uma identificação sobre suas origens e singularidades.

Dos 188 escravos crioulos, muitos vieram de diferentes províncias do Brasil: 15 da Bahia, 13 de Pernambuco, 1 do Ceará, 2 do Maranhão, 2 de Minas, 2 do Piauí, e 2 de São Paulo. Um aspecto interessante é a percepção sobre os regionalismos. Embora sejam poucos casos, apenas 5 no material consultado, eles evidenciam a sensibilidade para sotaques, como "fala à paulistana", ou "fala apaulistada", "fala à moda do norte", com destaque para a descrição de Pedro: "fala com muita pausa e sotaque bastante pronunciado da sua província donde é chegado há pouco tempo" (JC, 8/3/1852).

Bonifácio, de nação Moçambique, "fala muito brando" (JC, 9/6/1834). Luiz, Quilimane, sapateiro, era "bastante cioso fala" (DRJ, 4/1/1834). Já o marinheiro que fugiu da Sumaca Nova Sorte, chamado José, Mina, "pouco fala", embora costumasse entrar numa venda do Largo da Carioca "quando lá não está o dono, e mesmo quando está, para falar com uma preta do mesmo". José levara sua roupa surrada, mas "consta que agora anda bem vestido com roupa do Contramestre e Capitão que foi buscar à lavadeira" (DRJ, 27/12/1828). Ora, aqui o próprio relato indica que, se José era de poucas palavras, ele não as media para conversar com quem lhe interessasse.

A visão geral sobre as descrições nos aponta para uma interação linguística fluida. Por um lado, o que temos a deduzir é que os escravos, tanto crioulos como africanos, eram vistos como falantes desembaraçados. Mas por outro lado, devemos procurar o que estas descrições revelam sobre os próprios senhores e sobre como viviam a língua corrente na cidade. Se aos ouvidos dos senhores os escravos se comunicavam bem, isso pode nos levar a supor que esses escravos influenciavam o falar corrente e cotidiano. Os estudos linguísticos atuais têm investigado as influências na sintaxe no português do Brasil dadas pela situação de contato com as línguas africanas. Indo muito além do vocabulário, aponta-se para formas correntes que passaram ao vernáculo, à língua falada do dia a dia, que poderiam ser explicadas por características específicas de tais línguas, sobretudo as do grupo banto (Lipsky, 2008; Petter e Fiorin, 2008; Galves, 2009). A perspectiva da história social aqui apresentada, que aponta uma distância entre tais descrições dispersas nos registros e as representações intelectuais contemporâneas que desqualificavam o falar dos escravos, pode contribuir para a compreensão desse contato. 
1. O próprio Observatório da Língua Portuguesa pretende atuar em prol do que define como "língua veicular de ensino e aprendizagem", ou "língua de acesso à informação", ou ainda "língua de comunicação política entre organizações internacionais", evidenciando que os sujeitos de sua ação não falariam naturalmente ou espontaneamente essa língua, e que se trata antes de uma política linguística que se propõe determinados fins. Ver http:// observatorio-lp.sapo.pt/pt/quem-somos/op coes-estrategicas. Acesso em maio de 2012.

2. Os anos iniciais referem-se à data em que tais jornais passaram a circular. $\mathrm{O}$ período coincide com o processo de independência do país, abarcando a lei de 1831 que tornou ilegal o tráfico de escravos, bem como o fim efetivo do tráfico em 1850 . O ano de 1870 foi escolhido em função de ser uma data considerada um divisor tanto para a história social da escravidão, com o fim da Guerra do Paraguai e a Lei do Ventre Livre no ano seguinte, como também para a história intelectual, que aponta mudanças de paradigmas teóricos no entendimento da nacionalidade e da sociedade. De qualquer forma, em 1870 os anúncios tornam-se de fato mais raros. O critério básico de recolha desses anúncios foi mapear formas distintas através das quais os proprietários descreveram seus escravos do ponto de vista do uso da língua, sem a proposta de recolher exaustivamente todos os anúncios publicados, e procurando ao menos cerca de 15 a 20 anúncios a cada ano. A disponibilidade de jornais para consulta na Fundação Biblioteca Nacional também condicionou a pesquisa. Outro aspecto metodológico é que procuramos ao máximo localizar e excluir possíveis repetições sobre os mesmos indivíduos.

3. Embora tenha havido também constrangimentos importantes, dados pela ilegitimidade do cativeiro a partir de 1831 . Naquele contexto descrever um escravo como um recém-chegado tornaria notória a ilegalidade da situação (Abreu, 2012; Chalhoub, 2011).

4. Certamente a "boa habilidade linguística" é aqui considerada a partir das descrições feitas, sinalizando o que os grupos sociais envolvidos entendiam como tal. Não caberia ao historiador avaliar uma boa ou fraca habilidade em termos absolutos. Mas o que importa é entender as relações travadas por esses grupos.

5. Como pode haver mais de uma descrição para o mesmo indivíduo, optei por selecionar na classificação apresentada nas duas tabelas aquela que fosse mais representativa. Por exemplo, se um escravo é apresentado como bem falante, e voz grossa, indiquei o primeiro elemento. No grupo dos que sabem ler e escrever, considerei essa característica.

6. A análise detalhada desta tabela foi feita em outro trabalho ainda inédito, e demos aqui uma síntese sobre o grupo dos africanos. 


\section{Referências bibliográficas}

Constituição da República dos Estados Unidos do Brasil (de 16 de julho de 1934) http://www.planalto.gov.br/ccivil_03/const ituicao/constituicao34.htm

Decreto-lei n. 406 de 4 de maio de 1938. Dispõe sobre a entrada de estrangeiros no território nacional http://www6.senado. gov.br/ legislacao/ListaPublicacoes.action ?id $=12803$

Constituição dos Estados Unidos do Brasil (de 18 de setembro de 1946) http://www. planalto.gov.br/ccivil_03/constituicao/cons tituiçao46.htm

Constituição da República Federativa do Brasil de 1967 http://www.planalto.gov.br/ ccivil_03/constituicao/Constituiçao67.htm

Constituição da República Federativa do Brasil de 1988 http://www.planalto.gov. br/ccivil_03/constituicao/constituiçao.htm

ABREU, Marcos. Ladinos e boçais: o regime de línguas do contrabando de africanos (1831-c.1850). Dissertação de Mestrado. Programa de Pós-Graduação em História Social. Unicamp, 2012.

ALKMIM, Tania (org.). Para a história do português brasileiro. São Paulo: Humanitas, 2002.

A fala como marca. Os escravos nos anúncios de Gilberto Freyre. Scripta, Belo Horizonte, vol. 9, $\mathrm{n}^{\mathrm{o}}$ 18, 2006, p. 221-29.

Falas e cores: um estudo sobre o português de negros e escravos no Brasil do século XIX. In: LIMA, Ivana Stolze \& CARMO, Laura (org). História social da língua nacional. Rio de Janeiro: Edições Casa de Rui Barbosa, 2008.

Um texto inaugural: o visconde da Pedra Branca e o português do Brasil. Stockholm Review in Latin American Studies 8,
2012, p. 21-33. Disponível em: http://www. lai.su.se/gallery/bilagor/SROLAS_08_201 2_Tania_Alkmim.pdf.

CALVET, Louis-Jean. As políticas linguísticas. São Paulo: Parábola Editorial, 2007.

CASTRO, Yeda Pessoa de. A língua minajeje no Brasil: um falar africano em Ouro Preto do século XVIII. Belo Horizonte: Fundação João Pinheiro, 2002.

CERTEAU, Michel de; JULIA, Dominique et al. Une politique de la langue - La Révolution Française et les patois: l'enquête de Grégoire. Paris: Gallimard, 1975.

CHALHOUB, Sidney. Visões da liberdadeuma história das últimas décadas da escravidão na Corte. São Paulo: Companhia das Letras, 1990.

A política da linguagem no cotidiano da escravização ilegal. (Brasil, décadas de 1830 a 1850) Conferência proferida no Seminário Dinâmicas Afro-latinas: língua (s) e história (s). Instituto de Estudos da Linguagem, Unicamp, 27 de abril de 2011.

COELHO, Olga Ferreira. Os nomes da língua: configuração e desdobramentos do debate sobre a língua brasileira no século XIX. Revista IEB 47, 2008, p. 139-160.

FRAGOSO, João \& FLORENTINO, Manolo. A comunidade de mercadores do Rio de Janeiro e o mercado atlântico português na passagem do século XVIII para o século XIX. In: ALMEIDA, Miguel Valle de e outros (org). Trânsitos coloniais. Lisboa: Imprensa de Ciências Sociais, 2002, p. 345366.

FREIRE, José Bessa. Rio Babel: a história das línguas na Amazônia. Rio de Janeiro: Eduerj/Atlântica, 2004. 
GALVES, Charlotte, GARMES, Hélder \& RIBEIRO, Fernando Rosa (org). ÁfricaBrasil: caminhos da língua portuguesa. Campinas: Editora Unicamp, 2009.

GOMES, Flavio dos Santos. $A$ hidra e os pântanos: mocambos, quilombos e comunidades de fugitivos no Brasil. São Paulo: Unesp/Pólis, 2005.

GUISAN, Pierre. Língua: a ambiguidade do conceito. In: BARRETO, Monica Maria G. Saavedra \& SALGADO, Ana Claudia Peters (org). Sociolinguística no Brasil: uma contribuição dos estudos sobre línguas em/de contato. Homenagem ao professor fürgen Heye. Rio de Janeiro: 7 Letras/Faperj, 2009, p. 17-27.

HOLANDA, Sérgio Buarque. Raizes do Brasil. [1936]. Rio de Janeiro: José Olímpio, 1971.

LARA, Silvia. Linguagem, domínio senhorial e identidade étnica nas Minas Gerais de meados do século XVIII. In: ALMEIDA, Miguel Valle de e outros (org). Trânsitos coloniais. Lisboa: Imprensa de Ciências Sociais, 2002, p. 205-225.

LEE, Kittiya. Conversing in colony. The Brasilica and the vulgar in Portuguese America. Tese de doutorado em Filosofia. Baltimore, The Johns Hopkins University, 2005.

LIMA, Ivana Stolze. Entre a língua nacional e a fala caçanje. Representações sociais sobre a língua no Rio de Janeiro Imperial. In: OLIVEIRA, Cecilia Helena de Sales \& COSTA, Wilma Peres (org).De um império a outro. Estudos sobre a formação do Brasil, séculos XVIII e XIX. São Paulo: Fapesp/Hucitec, 2007, p. 63-99.

\footnotetext{
- Língua nacional, histórias de um velho surrão. In: LIMA, Ivana Stolze \& CARMO, Laura do (org). História social da língua nacional. Rio de Janeiro: Edições Casa de Rui Barbosa, 2008, p. 215-245.
}

LIPSKI, John. Angola e Brasil. Vínculos linguísticos Afro-lusitanos. Veredas, Porto Alegre, 9, 2008, p. 83-98.

LUCCHESI, Dante. Africanos, crioulos e a língua portuguesa. In: LIMA, Ivana Stolze \& CARMO, Laura do (org). História social da língua nacional. Rio de Janeiro: Edições Casa de Rui Barbosa, 2008, p. 151-180.

MARIANI, Bethania. Colonização linguística: línguas, política e religião no Brasil (séculos XVI a XVIII) e nos Estados Unidos da América (século XVIII). Campinas: Pontes, 2004.

MARTINS, Nilce Sant'Anna. História da língua portuguesa. Século XIX. São Paulo: Ática, 1988.

MATTOS, Ilmar Rohloff de. O tempo Saquarema - A formação do Estado imperial [1987]. São Paulo: Hucitec, 1990.

MELLO, Heliana Ribeiro de. The genesis and develpment of Brazilian vernacular Portuguese. The City University of New York, 1996.

OLIVEIRA, Klebson \& LOBO, Tania C. F. Escrita liberta: letramento de negros forros na Bahia do século XIX. In: CASTILHO, Ataliba de \& MORAIS, Maria Aparecida Torres (org). Descrição, história e aquisiçãa do português brasileiro. Vol. 437-460. Campinas: Pontes/Fapesp, 2007.

PEIXOTO, Antonio da Costa. Obra nova da língua geral de mina. Lisboa: Agência Geral das Colônias, 1945 (edição do manuscrito de 1741).

PETTER, Margarida \& FIORIN, Jose Luis. África no Brasil: a formação da língua portuguesa. São Paulo: Contexto, 2008.

PINTO, Edith Pimentel. $O$ português do Brasil: textos críticos e teóricos, 1 -1820-1920, fontes para a teoria e a história. São Paulo/Rio de Janeiro: Edusp/Livros técnicos e científicos, 1978. 
- O português no Brasil: época colonial. In: PIZARRO, Ana (org). América Latina: palavra, literatura e cultura. vol. 1 . São Paulo/Campinas: Memorial/Unicamp, 1993.

PINTO, Luís Maria da Silva. Dicionário de língua brasileira. Ouro Preto: Tipografia de Silva, 1932.

RODRIGUES, João Paulo Coelho de Souza. A pátria e a flor: língua, literatura e identidade nacional no Brasil, 1840-1930. Unicamp, 2002.

RODRIGUES, José Honório. A vitória da língua portuguesa no Brasil colonial, $\mathrm{Hu}$ manidades, vol. I, n. 4, jul/set 1983, p.21-41.

RUBIM, Brás da Costa. Vocabulário brasileiro para servir de complemento aos dicionários da língua portuguesa. Rio de Janeiro: Tipografia Dois de Dezembro, 1853.

SANCHES, Edgar. A língua brasileira. São Paulo: Cia. Ed. Nacional, 1940. (Coleção Brasiliana, vol. 179)

SILVA, Adriana Maria Paulo da. Aprender com perfeiçãa e sem coação: uma escola para meninos pretos e pardos na Corte. Brasília: Editora Plano, 2000.

SILVA, Rosa Virgínia Mattos e (ed.). Para a história do português brasileiro. São Paulo: Humanitas/FFLCH/USP/Fapesp, 2001.
SLENES, Robert. Malungu, ngoma vem! África coberta e descoberta no Brasil. Revista USP, 12, 1992, p. 48-67.

SOUZA, Patrícia March de. Visualidade da escravidão. Representações e práticas de vestuário no cotidiano dos escravos na cidade do Rio de Janeiro oitocentista. Tese de doutorado. Programa de Pós-Graduação em História Social da Cultura, PUC-Rio, 2011.

SÜSSEKIND, Flora. O escritor como genealogista: a função da literatura e a língua literária no romantismo brasileiro. In: PIZARRO, Ana (org). América Latina: palavra, literatura e cultura. São Paulo/Campinas: Memorial/Unicamp, 1994.

VARNHAGEN, Francisco A. História geral do Brasil antes de sua separação e independência de Portugal. São Paulo: Melhoramentos, 1854-1857. $8^{\mathrm{a}}$ ed. integral, 1975.

VILLALTA, Luiz Carlos. O que se fala e o que se lê: língua, instrução e leitura. In: SOUZA, Laura de Mello e (org). História da vida privada no Brasil: cotidiano e vida privada na América Portuguesa. vol. 1. São Paulo: Companhia das Letras, 1997.

WISSENBACH, Maria Cristina. Cartas, procurações, escapulários e patuás: os múltiplos significados da escrita entre escravos e forros na sociedade oitocentista brasileira. Revista Brasileira de História da Educação, $\mathrm{n}$. 4, 2002.

\section{Resumo}

Este artigo propõe articular aspectos históricos da nacionalização linguística do Brasil à escravidão de africanos e descendentes no período de formação do Estado nacional (c. 1822-1870). Além da discussão de alguns paradigmas intelectuais, a análise de anúncios de jornal relativos a fugas de escravos evidenciará a dimensão linguística das relações entre os grupos sociais envolvidos. 
Palavras chaves: nacionalização linguística no Brasil; escravidão; Brasil Império
Abstract
This article examines historical aspects of linguistic nationalization in Brazil relating them to the enslavement of Africans and their descendents during the period of State formation (c. 1822-1870). In addition to the discussion of a few intellectual paradigms, the analysis of newspaper notices of slaves' flights demonstrates the linguistic dimension of the relationship between the social groups involved.

Key words: linguistic nationalization in Brazil; slavery; imperial Brazil.

\section{Résumé}

Cet article propose une articulation entre des aspects historiques de la nationalisation linguistique au Brésil et l'esclavage des africains et de leurs descendents au moment de la formation de l'État national (c. 1822-1870). Au dela de la discussion de quelques paradigmes intellectuels, l'analyse des notes publiées dans des journaux sur la fuite d'esclaves rendra évidente la dimension linguistique des rapports entre les groupes sociaux em question. Mots-clés: nationalisation linguistique au Brésil; esclavage; lr Brésil imperial. 